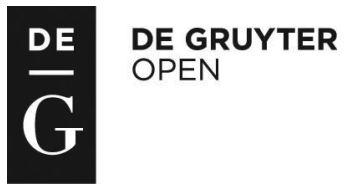

\title{
THE EFFECT OF BODY CONDITION SCORE ON THE BIOCHEMICAL BLOOD INDICES AND REPRODUCTIVE PERFORMANCE OF DAIRY COWS*
}

\author{
Barbara Stefańska ${ }^{1 \bullet}$, Włodzimierz Nowak ${ }^{1}$ Ewa Pruszyńska-Oszmałek², Robert Mikuła ${ }^{1}$, \\ Daniel Stanisławski ${ }^{3}$, Małgorzata Kasprowicz-Potocka ${ }^{1}$, Andrzej Frankiewicz ${ }^{1}$, Paweł Maćkowiak ${ }^{2}$ \\ ${ }^{1}$ Department of Animal Nutrition and Feed Management, University of Life Sciences, Wołyńska 33, \\ 60-637 Poznań, Poland \\ ${ }^{2}$ Department of Animal Physiology and Biochemistry, University of Life Science, Wołyńska 35, \\ 60-637 Poznań, Poland \\ ${ }^{3}$ Computer Lab, University of Life Sciences, Wołyńska 33, 60-637 Poznań, Poland \\ •Corresponding author: basianowak88@wp.pl
}

\begin{abstract}
The aim of the study was to investigate the effect of BCS (Body Condition Score) on the calving day and its decrease during early lactation on the biochemical blood indices and reproductive performance. One hundred and thirty-one Polish Holstein-Friesian cows were divided into three groups according to the North-American body condition score on the calving day (AC $\leq 3.5$ point BCS; MID 3.51-3.75 point BCS; FAT $>3.75$ point BCS) and according to the decrease in BCS during early lactation (HG $>0.49$ point $B C S$; WEL $0.49-0.25$ point $B C S, L<0.25$ point $B C S$ ). In current study, significant interaction between change of BCS during early lactation and time of blood sampling on BHBA concentration was observed. In the AC group ( $\leq 3.5 \mathrm{BCS})$, the highest concentrations of glucose on 3 and $5 \mathrm{~d}$ of lactation compared to the MID and FAT groups and of insulin on $28 \mathrm{~d}$ and also IGF-I on 5 and $28 \mathrm{~d}$ of lactation compared to the FAT group were recorded. In the FAT group, the highest concentration of NEFA on 3 and $5 \mathrm{~d}$ compared to the AC group and of BHBA on $28 \mathrm{~d}$ of lactation compared to the MID group was recorded. The body condition score on the parturition day affected the reproductive performance; in the FAT group ( $>3.75$ BCS) the lowest conception rate of the first insemination, insemination index and thereby the longest days open were observed. The highest decreases in BCS (HG $>0.49$ points) resulted in increased concentrations of NEFA on $3 \mathrm{~d}$ and of BHBA on 3 and $5 \mathrm{~d}$. Moreover, in the HG group, the lowest concentration of $T_{3}$ on 3,5 and $28 \mathrm{~d}$ as compared to the WEL group was recorded. We concluded that the BCS ( $>3.5$ points) on the calving day had a significantly negative effect on the metabolic status of dairy cows in the postpartum period estimated by the concentration of biochemical blood indices characterising carbohydrates (IGF-I, insulin) and lipid (NEFA, BHBA) metabolism and also the reproductive performance such as the conception rate of the first insemination, insemination index, days open. We suggested that the blood serum concentrations of IGF-I and NEFA were the most sensitive biochemical markers of the metabolic status of dairy cows in our study.
\end{abstract}

Key words: dairy cow, body condition score, fertility, metabolite and hormone indices

\footnotetext{
* Supported by the Polish State Committee for Scientific Research, Grant No. N N311 266734.
} 
The transition from pregnancy to lactation is a crucial period for the profitability of dairy cows. Increased milk production often results in metabolic diseases during the early postpartum period (Akbar et al., 2015). The dry matter intake of a highyielding dairy cow in early lactation is insufficient to meet the requirement of milk production, which causes a negative energy balance (NEB). This status is associated with a change in metabolism, which has a negative effect on the reproductive performance (Chandra et al., 2011). Typical changes during early lactation, associated with negative energy balance, are lower concentrations of glucose, insulin, IGF-I and higher concentrations of NEFA and BHBA (van Dorland et al., 2009; Gross et al., 2011; Cincovic el al., 2012). If the amount of ingested nutrients and mobilized endogenous energy is enough to cover the increased energy demands, lactation is maintained and dairy cows health is uncompromised, but they experience a dramatic body condition loss during the first weeks of lactation (Gerloff, 2000). Moreover, metabolic disorders in this period are related to a decrease in fertility. The energy deficits delay the resumption of postpartum oestrous cycles and reduce the conception rate of the first insemination (Butler, 2000). This shows that the duration of the NEB is positively associated with the interval until the first postpartum ovulation (Chandra et al., 2011). The body condition score is a reliable, simple method of estimating the nutritional status of cows. The body condition score assesses the stored energy fat reserves of the dairy cows and it is therefore linked to the energy balance status and fertility (Chagas et al., 2007). BCS at calving day may affect early lactation dry matter intake (DMI), milk yield, cow immunity and reproductive performance. Matthews et al. (2012) suggested that DMI and BCS at calving day are negatively correlated and lead to negative energy balance (NEB). For cows with BCS $>3.5$ during the transition from late gestation to early lactation, considerable amounts of adipose tissue are mobilized, resulting in elevated plasma NEFA to support increased energy requirements in dairy cows (Locher at al., 2015). Circulating NEFA can be oxidized in the hepatocytes or exported as constituents of very low density lipoproteins (VLDL). However, postpartum release of NEFA from adipose tissue mostly exceeds the needs and oxidation capabilities of the liver (Locher et al., 2015) and causes formation of ketone bodies including BHBA and reesterification to triglycerides (TG). The latter are stored in hepatocytes and implicate the development of fatty liver, reduced metabolic function, health status, production, and reproductive performance, as well as incidence and severity of metabolic disorders and infectious diseases (Akbar et al., 2015). NEB delayed the start of the ovarian activity, reduced the number of oestrus, extending the days open (Roche et al., 2013). Moreover, negative energy balance, metabolic diseases, and infections of the uterus are the major weakness of the secretion of luteinizing hormone (LH), which affects the dominant follicle maturation and ovulation (Chagas et al., 2007). Recent studies have also indicated that the resulting energy deficit determines the quality of oocytes, which reflect changes in the biochemical composition of follicular fluid (Konigsson et al., 2008). Many authors agree that controlling BCS of highyielding dairy cows could minimize the effect of negative energy balance, which is one of the most important reasons for poor reproductive performance (Chagas et al., 2007). 
The aim of the study was to investigate the effects of the body condition score on the calving day and its decrease during early lactation on the biochemical blood indices and reproductive performance of dairy cows. We hypothesized that the body condition score may influence blood biochemical indices of lipid and carbohydrate metabolism of high-yielding dairy cows. BCS on the calving day as well as a decrease in BCS during early lactation may determine fertility of dairy cows.

\section{Material and methods}

All procedures were approved by Local Ethical Committee No.10 in Poznań, Poland (64/2007).

The experiment was performed on a farm in Wielkopolska. The study covered the period from the calving day over to the first 200 days of lactation. At the beginning of the study, animals were selected based on the analogue principle including BW (body weight), BCS at dry-off, parity, breed and previous lactation milk yield. The average value of milk yield in lactation of $10,500 \mathrm{~kg}$ of milk was recorded before the experiment. The dates of cow's milk performance by the Polish Federation of Cattle Breeders and Dairy Farmers were conducted. Cows were housed at the free-stall cowshed.

One hundred and thirty-one Polish Holstein-Friesian clinically healthy, pregnant dairy cows were divided according to the methodology shown by Edmonson et al. (1989) in North-American body condition score (0 to 5 point scale) into three groups on the calving day as acceptable ( $\mathrm{AC} \leq 3.5, \mathrm{n}=51$ ), medium (MID 3.51-3.75, $\mathrm{n}=59)$ and overfed (FAT $>3.75, \mathrm{n}=21)$. The same cows were further divided into three groups according to the decrease in BCS during first 56 days of lactation as high ( $\mathrm{HG}>0.49, \mathrm{n}=36$ ), well (WEL 0.49-0.25, $\mathrm{n}=54)$ and low $(\mathrm{L}<0.25, \mathrm{n}=41)$.

The diets were balanced according to the recommendation of the French INRA system (INRATION 3.3). The nutritional value of the feed components was estimated by the PrevAlim 3.23. Weekly forage, concentrate and TMR samples were tested for monthly analysis by wet chemistry for crude protein (CP, method no. 976.05), neutral detergent fibre (NDF, method no. 942.05), acid detergent fibre (ADF method no. 973.18), calcium (Ca method no. 6869) and phosphorus (P method no. 6491) (AOAC, 2007). The diets (Table 1) were based on silage made of alfalfa, maize, grass and concentrates: soybean meal, triticale grain, barley grain and mineral and vitamin supplements, and fed as the total mixed ration (TMR) at 9 a.m. and 2.30 p.m. for the entire experimental period. From 1 to $21 \mathrm{~d}$ of lactation, all cows were fed the same fresh, transition diet (0.82 UFL/kg DM, 35.3\% NDF, $16.5 \% \mathrm{CP})$ to provide adequate energy for a cow with a body weight of $650 \mathrm{~kg}$ and daily milk production of $30 \mathrm{~kg}$. From 22 to $200 \mathrm{~d}$ of lactation cows were fed lactational diet $(0.90 \mathrm{UFL} / \mathrm{kg}$ DM, $28.5 \% \mathrm{NDF}, 17.4 \% \mathrm{CP}$ ) calculated for daily milk production of $44 \mathrm{~kg}$.

The body condition score was performed by one person in accordance with the methodology shown by Edmonson et al. (1989) on the parturition day (in the first 12 hours after calving) and on 14 and $56 \mathrm{~d}$ of lactation. 
Table 1. Ingredient and nutrient composition of total mixed ration (TMR) diets

\begin{tabular}{|c|c|c|}
\hline Ingredients ( $\%$ of DM) & Transition $\operatorname{diet}^{1}$ & Lactation $\operatorname{diet}^{2}$ \\
\hline Alfalfa silage & 12.8 & 17.6 \\
\hline Maize silage & 20.0 & 20.0 \\
\hline Grass silage & 11.8 & \\
\hline Maize grain silage & 9.7 & 7.1 \\
\hline Sugar beet pulp silage & 5.6 & 6.7 \\
\hline Brewer's grain silage & 7.1 & 6.2 \\
\hline Hay & 6.7 & 6.4 \\
\hline Soybean meal & 9.0 & 9.2 \\
\hline Barley grain & 5.8 & 8.5 \\
\hline Triticale grain & 5.3 & 8.5 \\
\hline Rapeseed meal & & 4.0 \\
\hline Glycerol $99 \%$ & 1.3 & \\
\hline Fat $100 \%$ & & 2.2 \\
\hline Minerals and vitamins & 4.9 & 3.6 \\
\hline \multicolumn{3}{|l|}{ Nutrient concentration (in $1 \mathrm{~kg} \mathrm{DM}$ ) } \\
\hline UFL & 0.82 & 0.90 \\
\hline PDIN (g) & 98 & 111 \\
\hline PDIE (g) & 98 & 105 \\
\hline $\mathrm{CP}(\%)$ & 16.5 & 17.4 \\
\hline NDF (\%) & 35.3 & 28.5 \\
\hline $\operatorname{ADF}(\%)$ & 20.3 & 18.9 \\
\hline $\mathrm{Ca}(\mathrm{g})$ & 8.7 & 9.4 \\
\hline$P(g)$ & 3.6 & 3.7 \\
\hline
\end{tabular}

${ }^{1}$ feeding period from 1 to $21 \mathrm{~d}$ of lactation; ${ }^{2}$ feeding period from $22 \mathrm{~d}$ to $200 \mathrm{~d}$ of lactation.

UFL: feed units for lactation; PDIE: protein digested in the small intestine when rumen-fermentable energy is limiting; PDIN: protein digested in the small intestine when rumen-fermentable nitrogen is limiting.

Reproductive performance, such as days to the first ovulation, conception rate of the first insemination, insemination index and days open to 200 days of lactation, were also recorded. The first ovulation was identified by transrectal ultrasonography using a colour Doppler ultrasound scanner (SSD-5500, Aloka Co., Tokyo, Japan) equipped with a 7.5-MHz convex transducer (UST-995-7.5, Aloka CO.) (Kawashima el al., 2007).

Blood was sampled from the jugular vein 3 hours after morning feeding on 3 , 5 and $28 \mathrm{~d}$ of lactation. Blood samples were collected into tubes with polystyrene separating granules covered with a clot activator and then the aliquots were rotated in a centrifuge; next, the serum was frozen $\left(-20^{\circ} \mathrm{C}\right)$ and stored for later analyses. The concentration of glucose, $\beta$-hydroxybutyrate (BHBA) and activity of aspartate aminotransferase (AST) was analyzed colorimetrically, using a Marcel Media spectrophotometer with a Pointe Scientific kit reagent. The concentrations of nonesterified fatty acids (NEFA) were analyzed according to the Duncomble's colorimetric method (Duncomble, 1964). Serum hormone concentrations were analyzed by means of radioimmunoassay (RIA): insulin (Millipore Corporation, kit no. PI-12k), insulin- 
like growth factor-I (IGF-I: Diagnostic System Lab, no. SEA050 Bo), triiodothyronine $\left(\mathrm{T}_{3}\right.$ : CIS International; kit no. OCPE07- $\left.\mathrm{T}_{3}\right)$ and thyroxine $\left(\mathrm{T}_{4}\right.$ : CIS International; kit no. OCPG07-T 4 ). This is the immunochemical method which detects the reaction of the antigen with its specific antibody, based on the measurement of radioactivity of radioactive isotope labeled with one of the reaction components (antigen or antibody). It is used to determine the concentration of hormones, tumor antigens, autoantibodies and specific antibody class IgF and other compounds, e.g. medications and vitamins (Yellow et al., 1960). The concentrations of hormones were determined with isotope I 125, which undergoes gamma radiation, using a reader Automatic Gamma radiation, Gamma Counter 1470. The RIA test using curves with bovine serum of various dilution rates was validated and examined.

The results obtained were analyzed using the SAS computer software SAS 9.2 (2011) and the concentrations of NEFA, BHBA, AST, glucose, $\mathrm{T}_{3}, \mathrm{~T}_{4}$, IGF-I and insulin were analyzed using SAS MIXED PROCEDURE with repeated measures option and the model included group, time of blood sampling and their interaction as fixed effects. Also, repeated statement to indicate which variable indicates the different subject (subject $=$ cow) and the specific covariance structure among repeated measures were used. Moreover, detailed means were analyzed using Duncan's multiple range test and the PROC GLM procedure. Pearson phenotype correlation coefficients were calculated using the PROC CORR procedure. Statistical significance was declared at $\mathrm{P} \leq 0.05$ and trends were considered when $0.05<\mathrm{P} \leq 0.1$.

\section{Results}

In the current study, no interactions between group of BCS on calving day and time of blood sampling on metabolic blood indices were found (Table 2). In the AC group ( $\leq 3.5 \mathrm{BCS}$ ), significantly higher concentrations of glucose on 3 and $5 \mathrm{~d}$ compared to the MID and FAT groups were determined. Moreover, in the same group, significantly higher concentrations of insulin on $28 \mathrm{~d}(\mathrm{P} \leq 0.05)$ and of IGF-I on $5 \mathrm{~d}$ $(\mathrm{P} \leq 0.05)$ and $28 \mathrm{~d}(\mathrm{P} \leq 0.01)$ of lactation compared to the FAT group were recorded. In the FAT group, significantly higher concentrations of NEFA on 3 and $5 \mathrm{~d}$ as compared to AC group and of BHBA on $28 \mathrm{~d}$ of lactation compared to the MID group were recorded. BCS on calving day did not significantly affect the activity of AST and the concentration of thyroid hormones such as $\mathrm{T}_{3}$ and $\mathrm{T}_{4}$ (Table 3 ). Furthermore, a significant, negative correlation was observed between BCS on the calving day and concentrations of insulin on $28 \mathrm{~d}(\mathrm{r}=0.36)$ and of IGF-I on $5 \mathrm{~d}(\mathrm{r}=-0.32)$ and $28 \mathrm{~d}$ $(\mathrm{r}=-0.31)$. A positive correlation between BCS on the calving day and the concentration of NEFA on $3 \mathrm{~d}(\mathrm{r}=0.34)$ and $5 \mathrm{~d}$ of lactation $(\mathrm{r}=0.37)$ was noted (Table 4$)$. The body condition score on the parturition day influenced the reproductive performance. In the $\mathrm{AC}$ group a higher $(\mathrm{P} \leq 0.05)$ conception rate of the first insemination compared to the FAT group was recorded. Moreover, in the FAT group (>3.75 BCS) a significantly higher insemination index and the longest days open were observed (Table 5). 
Table 2. Effect of time and group BCS on calving day on blood serum metabolites

\begin{tabular}{|c|c|c|c|c|c|c|c|}
\hline \multirow{2}{*}{ Metabolite } & \multirow{2}{*}{ Group } & \multicolumn{3}{|c|}{ Time (d) } & \multicolumn{3}{|c|}{$\mathrm{P}$-value } \\
\hline & & 3 & 5 & 28 & time & group & time $\times$ group \\
\hline \multirow{3}{*}{$\begin{array}{l}\text { Glucose } \\
(\mathrm{mmol} / \mathrm{L})\end{array}$} & $\mathrm{AC}$ & 2.30 & 2.04 & 2.38 & & & \\
\hline & MID & 2.35 & 2.11 & 2.40 & 0.3086 & 0.0296 & 0.3563 \\
\hline & FAT & 3.75 & 3.04 & 2.35 & & & \\
\hline \multirow{3}{*}{$\begin{array}{l}\text { Insulin } \\
(\mu \mathrm{U} / \mathrm{mL})\end{array}$} & $\mathrm{AC}$ & 7.99 & 9.32 & 8.87 & & & \\
\hline & MID & 5.86 & 8.61 & 5.79 & 0.2719 & 0.0453 & 0.6627 \\
\hline & FAT & 7.89 & 7.73 & 3.01 & & & \\
\hline \multirow{3}{*}{$\begin{array}{l}\text { IGF-I } \\
(\mathrm{ng} / \mathrm{mL})\end{array}$} & $\mathrm{AC}$ & 92.76 & 145.60 & 212.13 & & & \\
\hline & MID & 89.83 & 87.35 & 188.56 & $<0.0001$ & 0.0050 & 0.5185 \\
\hline & FAT & 57.92 & 42.96 & 76.04 & & & \\
\hline \multirow{3}{*}{$\begin{array}{l}\mathrm{T}_{3} \\
(\mathrm{ng} / \mathrm{mL})\end{array}$} & $\mathrm{AC}$ & 0.87 & 0.66 & 1.09 & & & \\
\hline & MID & 0.87 & 0.56 & 1.02 & $<0.0001$ & 0.0592 & 0.9892 \\
\hline & FAT & 0.68 & 0.38 & 0.79 & & & \\
\hline \multirow{3}{*}{$\begin{array}{l}\mathrm{T}_{4} \\
(\mathrm{ng} / \mathrm{mL})\end{array}$} & $\mathrm{AC}$ & 44.09 & 22.17 & 39.77 & & & \\
\hline & MID & 36.69 & 21.91 & 36.55 & $<0.0001$ & 0.4519 & 0.8354 \\
\hline & FAT & 32.81 & 24.20 & 33.15 & & & \\
\hline \multirow{3}{*}{$\begin{array}{l}\text { NEFA } \\
(\mathrm{mmol} / \mathrm{L})\end{array}$} & $\mathrm{AC}$ & 0.70 & 0.68 & 0.40 & & & \\
\hline & MID & 0.76 & 1.00 & 0.53 & $<0.0001$ & 0.0060 & 0.1764 \\
\hline & FAT & 1.02 & 1.09 & 0.40 & & & \\
\hline \multirow{3}{*}{$\begin{array}{l}\text { BHBA } \\
(\mathrm{mmol} / \mathrm{L})\end{array}$} & $\mathrm{AC}$ & 0.74 & 0.94 & 0.76 & & & \\
\hline & MID & 0.75 & 0.82 & 0.65 & 0.1801 & 0.0453 & 0.9294 \\
\hline & FAT & 0.90 & 1.03 & 0.94 & & & \\
\hline \multirow{3}{*}{$\begin{array}{l}\text { AST } \\
(\mathrm{U} / \mathrm{I})\end{array}$} & $\mathrm{AC}$ & 68.85 & 53.12 & 56.41 & & & \\
\hline & MID & 70.25 & 65.54 & 62.47 & 0.0991 & 0.4487 & 0.9005 \\
\hline & FAT & 73.88 & 56.45 & 57.33 & & & \\
\hline
\end{tabular}

Experimental groups of BCS on calving day: AC $\leq 3.5$ BCS; MID 3.51-3.75 BCS; FAT $>3.75$ BCS. Bold values indicate significant effects.

Table 3. The effect of BCS on calving day on biochemical blood indices

\begin{tabular}{l|c|c|c|c}
\hline \multirow{2}{*}{ Item } & $\begin{array}{c}\text { Days of lactation } \\
\text { (day) }\end{array}$ & \multicolumn{3}{|c}{ Group (mean) } \\
\cline { 3 - 5 } \multicolumn{1}{c}{1} & 2 & $\mathrm{AC}$ & $\mathrm{MID}$ & FAT \\
\hline \multirow{2}{*}{ Glucose } & 3 & 3 & $2.35 \mathrm{~b}$ & $2.30 \mathrm{~b}$ \\
$(\mathrm{mmol} / \mathrm{L})$ & 5 & $3.72 \mathrm{a}$ & $2.11 \mathrm{~b}$ & $2.04 \mathrm{~b}$ \\
& 28 & $3.04 \mathrm{a}$ & 2.40 & 2.38 \\
Insulin & 3 & 2.35 & 5.86 & 7.89 \\
$(\mu \mathrm{U} / \mathrm{mL})$ & 5 & 7.99 & 8.61 & 7.73 \\
& 28 & 9.32 & $5.79 \mathrm{ab}$ & $3.01 \mathrm{~b}$ \\
$\mathrm{IGF}-\mathrm{I}$ & 3 & $8.87 \mathrm{a}$ & 89.83 & 57.92 \\
$(\mathrm{ng} / \mathrm{mL})$ & 5 & 92.76 & $87.35 \mathrm{ab}$ & $42.96 \mathrm{~b}$ \\
& 28 & $145.60 \mathrm{a}$ & $188.56 \mathrm{AB}$ & $76.04 \mathrm{~B}$ \\
$\mathrm{~T}_{3}$ & 3 & $212.13 \mathrm{~A}$ & $0.87 \pm 0.13$ & 0.68 \\
$(\mathrm{ng} / \mathrm{mL})$ & 5 & $0.87 \pm 0.13$ & $0.56 \pm 0.08$ & 0.38 \\
& 28 & $0.66 \pm 0.10$ & $1.02 \pm 0.09$ & 0.79 \\
\hline
\end{tabular}


Table 3 - contd.

\begin{tabular}{lccccc}
\hline \multicolumn{1}{c|}{1} & 2 & 3 & 4 & \\
\hline $\mathrm{T}_{4}$ & 3 & 44.09 & 36.69 & 32.81 \\
$(\mathrm{ng} / \mathrm{mL})$ & 5 & 22.17 & 21.91 & 24.20 \\
& 28 & 39.77 & 36.55 & 33.15 \\
$\mathrm{NEFA}$ & 3 & $0.70 \mathrm{a}$ & $0.76 \mathrm{a}$ & $1.02 \mathrm{~b}$ \\
$(\mathrm{mmol} / \mathrm{L})$ & 5 & $0.68 \mathrm{a}$ & $1.00 \mathrm{ab}$ & $1.09 \mathrm{~b}$ \\
& 28 & 0.40 & 0.53 & 0.40 \\
$\mathrm{BHBA}$ & 3 & 0.74 & 0.75 & 0.90 \\
$(\mathrm{mmol} / \mathrm{L})$ & 5 & 0.94 & 0.82 & 1.03 \\
& 28 & $0.76 \mathrm{ab}$ & $0.65 \mathrm{a}$ & $0.94 \mathrm{~b}$ \\
$\mathrm{AST}$ & 3 & 68.85 & 70.25 & 73.88 \\
$(\mathrm{U} / \mathrm{I})$ & 5 & 53.12 & 65.54 & 56.45 \\
& 28 & 56.41 & 62.47 & 57.33 \\
\hline
\end{tabular}

a, b, c- means with different letters different significantly, $\mathrm{P} 0.05$.

A, B, C - means with different letters different significantly, $\mathrm{P} \leq 0.01$

Experimental groups of BCS on calving day: AC $\leq 3.5$ BCS; MID 3.51-3.75 BCS; FAT $>3.75$ BCS.

Table 4. Correlation between BCS on calving day and its decrease during early lactation and biochemical blood indicates characterizing carbohydrate and lipid metabolism

\begin{tabular}{|c|c|c|c|c|}
\hline \multirow{2}{*}{ Indices (d) } & \multicolumn{2}{|c|}{ BCS on calving day } & \multicolumn{2}{|c|}{ Decrease of BCS } \\
\hline & correlation $(\mathrm{r})$ & significance $(\mathrm{P})$ & correlation $(\mathrm{r})$ & significance $(\mathrm{P})$ \\
\hline Glucose 3 & 0.31 & 0.08 & 0.04 & 0.83 \\
\hline Glucose 5 & 0.23 & 0.12 & 0.05 & 0.75 \\
\hline Glucose 28 & -0.10 & 0.51 & 0.11 & 0.44 \\
\hline $\mathrm{T}_{3} 3$ & -0.14 & 0.45 & $-0.29 *$ & 0.04 \\
\hline $\mathrm{T}_{3} 5$ & -0.17 & 0.25 & -0.15 & 0.30 \\
\hline $\mathrm{T}_{3} 28$ & -0.27 & 0.06 & -0.20 & 0.18 \\
\hline $\mathrm{T}_{4} 3$ & -0.15 & 0.41 & 0.15 & 0.39 \\
\hline $\mathrm{T}_{4} 5$ & 0.06 & 0.70 & -0.12 & 0.40 \\
\hline $\mathrm{T}_{4} 28$ & -0.16 & 0.28 & -0.18 & 0.22 \\
\hline Insulin 3 & 0.03 & 0.88 & -0.09 & 0.63 \\
\hline Insulin 5 & -0.02 & 0.88 & -0.03 & 0.85 \\
\hline Insulin 28 & $-0.36 * *$ & 0.01 & -0.15 & 0.29 \\
\hline IGF-I 3 & -0.09 & 0.62 & -0.19 & 0.29 \\
\hline IGF-I 5 & $-0.32 *$ & 0.03 & $-0.29 *$ & 0.05 \\
\hline IGF-I 28 & $-0.31 *$ & 0.03 & -0.14 & 0.33 \\
\hline BHBA 3 & 0.17 & 0.34 & $0.55 * *$ & 0.01 \\
\hline BHBA 5 & 0.05 & 0.73 & $0.47 * *$ & 0.01 \\
\hline BHBA 28 & 0.15 & 0.29 & -0.04 & 0.76 \\
\hline AST 3 & 0.11 & 0.56 & 0.21 & 0.24 \\
\hline AST 5 & 0.11 & 0.44 & 0.37 & 0.07 \\
\hline AST 28 & 0.05 & 0.75 & -0.14 & 0.35 \\
\hline NEFA 3 & $0.34 *$ & 0.05 & $0.35^{*}$ & 0.04 \\
\hline NEFA 5 & $0.37 * *$ & 0.01 & 0.10 & 0.48 \\
\hline NEFA 28 & 0.12 & 0.43 & 0.12 & 0.40 \\
\hline
\end{tabular}

** correlation statistically significant $\mathrm{P} \leq 0.01$; * correlation statistically significant $\mathrm{P} \leq 0.05$. 
Table 5. The effect of BCS on calving day on reproductive parameters

\begin{tabular}{l|c|c|c}
\hline \multirow{2}{*}{ Item } & \multicolumn{3}{c}{ Group (mean) } \\
\cline { 2 - 4 } & $\mathrm{AC}$ & MID & FAT \\
\hline Days to first ovulation & 25.19 & 25.29 & 24.29 \\
The conception rate of the first insemination & $0.57 \mathrm{a}$ & $0.38 \mathrm{ab}$ & $0.14 \mathrm{~b}$ \\
Insemination index & $2.62 \mathrm{ab}$ & $1.76 \mathrm{~b}$ & $4.0 \mathrm{a}$ \\
Days open & $144.57 \mathrm{ab}$ & $102.81 \mathrm{a}$ & $183.43 \mathrm{~b}$ \\
\hline
\end{tabular}

$\mathrm{a}, \mathrm{b}, \mathrm{c}-$ means with different letters different significantly, $\mathrm{P} \leq 0.05$.

Experimental groups of BCS on calving day: AC $\leq 3.5$ BCS; MID 3.51-3.75 BCS; FAT $>3.75$ BCS.

Table 6. Effect of time and BCS group decrease during early lactation on blood serum metabolites

\begin{tabular}{|c|c|c|c|c|c|c|c|}
\hline \multirow{2}{*}{ Metabolite } & \multirow{2}{*}{ Group } & \multicolumn{3}{|c|}{ Time $(\mathrm{d})$} & \multicolumn{3}{|c|}{ P-value } \\
\hline & & 3 & 5 & 28 & time & group & time $\times$ group \\
\hline \multirow{3}{*}{$\begin{array}{l}\text { Glucose } \\
(\mathrm{mmol} / \mathrm{L})\end{array}$} & $\mathrm{HG}$ & 2.99 & 2.34 & 2.40 & & & \\
\hline & WEL & 2.37 & 2.34 & 2.44 & 0.2762 & 0.5891 & 0.7113 \\
\hline & $\mathrm{L}$ & 2.60 & 1.88 & 2.30 & & & \\
\hline \multirow{3}{*}{$\begin{array}{l}\text { Insulin } \\
(\mu \mathrm{U} / \mathrm{mL})\end{array}$} & $\mathrm{HG}$ & 6.90 & 7.65 & 4.85 & & & \\
\hline & WEL & 6.82 & 10.50 & 6.98 & 0.4100 & 0.6054 & 0.6371 \\
\hline & L & 6.91 & 7.15 & 8.02 & & & \\
\hline \multirow{3}{*}{$\begin{array}{l}\text { IGF-I } \\
(\mathrm{ng} / \mathrm{mL})\end{array}$} & HG & 50.81 & 59.53 & 127.71 & & & \\
\hline & WEL & 98.67 & 110.38 & 202.91 & $<0.0001$ & 0.0459 & 0.8879 \\
\hline & $\mathrm{L}$ & 97.66 & 142.18 & 201.60 & & & \\
\hline \multirow{3}{*}{$\begin{array}{l}\mathrm{T}_{3} \\
(\mathrm{ng} / \mathrm{mL})\end{array}$} & HG & 0.56 & 0.42 & 0.79 & & & \\
\hline & WEL & 1.05 & 0.69 & 1.15 & $<0.0001$ & 0.0020 & 0.6604 \\
\hline & $\mathrm{L}$ & 0.80 & 0.55 & 1.03 & & & \\
\hline \multirow{3}{*}{$\begin{array}{l}\mathrm{T}_{4} \\
(\mathrm{ng} / \mathrm{mL})\end{array}$} & $\mathrm{HG}$ & 40.88 & 19.98 & 32.93 & & & \\
\hline & WEL & 43.98 & 23.53 & 40.56 & $<0.0001$ & 0.1746 & 0.2978 \\
\hline & $\mathrm{L}$ & 26.97 & 22.70 & 36.75 & & & \\
\hline \multirow{3}{*}{$\begin{array}{l}\text { NEFA } \\
(\mathrm{mmol} / \mathrm{L})\end{array}$} & HG & 1.02 & 0.95 & 0.47 & & & \\
\hline & WEL & 0.70 & 0.85 & 0.44 & $<0.0001$ & 0.0418 & 0.4567 \\
\hline & L & 0.69 & 0.84 & 0.47 & & & \\
\hline \multirow{3}{*}{$\begin{array}{l}\mathrm{BHBA} \\
(\mathrm{mmol} / \mathrm{L})\end{array}$} & HG & 1.01 & 1.26 & 0.75 & & & \\
\hline & WEL & 0.68 & 0.76 & 0.72 & 0.0034 & 0.0178 & 0.0076 \\
\hline & L & 0.68 & 0.79 & 0.76 & & & \\
\hline \multirow{3}{*}{$\begin{array}{l}\text { AST } \\
(\mathrm{U} / \mathrm{I})\end{array}$} & $\mathrm{HG}$ & 78.06 & 75.89 & 54.33 & & & \\
\hline & WEL & 66.78 & 53.96 & 60.15 & 0.1100 & 0.2590 & 0.1290 \\
\hline & L & 68.24 & 50.96 & 62.01 & & & \\
\hline
\end{tabular}

Experimental groups' decrease of BCS from calving day to $56 \mathrm{~d}$ of lactation: $\mathrm{HG}>0.49 \mathrm{BCS}$; WEL 0.49-0.25 BCS; L $<0.25$ BCS.

Bold values indicate significant effects.

In current study, significant interactions between decrease groups of $\mathrm{BCS}$ during early lactation and time of blood sampling on concentration BHBA were observed. In $\mathrm{HG}$ group $(>0.49 \mathrm{BCS}$ ) the higher concentration of BHBA, exceeding the reference value $(0.6-1.0 \mathrm{mmol} / \mathrm{L})$ at 1 week postpartum was analyzed (Table 6). Moreover, the highest decreases in BCS ( $\mathrm{HG}>0.49$ points) from calving day to $56 \mathrm{~d}$ of lactation resulted in increased concentrations of NEFA on $3 \mathrm{~d}(\mathrm{P} \leq 0.05)$ and of BHBA on $3 \mathrm{~d}(\mathrm{P} \leq 0.01)$ and on $5 \mathrm{~d}(\mathrm{P} \leq 0.01)$. Furthermore, a positive correlation between 
the decrease in BCS during early lactation and the concentration of NEFA on $3 \mathrm{~d}$ $(\mathrm{r}=0.35)$ and $5 \mathrm{~d}(\mathrm{r}=0.37)$ and of BHBA on $3 \mathrm{~d}(\mathrm{r}=0.55)$ and $5 \mathrm{~d}(0.47)$ of lactation was noted (Table 4). In the HG group, significant concentrations of $\mathrm{T}_{3}$ on 3,5 and 28 d compared to the WEL group $(\mathrm{P} \leq 0.05)$ were recorded (Table 7). Moreover, there was noted a significant negative correlation between the decrease in BCS during early lactation and concentrations of IGF-I on $5 \mathrm{~d}(\mathrm{r}=-0.29)$ and $\mathrm{T}_{3}$ on $3 \mathrm{~d}(\mathrm{r}=-0.29)$ (Table 4). The level of the BCS decrease during early lactation did not significantly affect the activity of AST and the concentration of glucose, insulin, IGF-I, $\mathrm{T}_{4}$ as well as the reproductive performance (Table 8).

Table 7. The effect of BCS decrease during early lactation on biochemical blood indices

\begin{tabular}{|c|c|c|c|c|}
\hline \multirow{2}{*}{ Item } & \multirow{2}{*}{$\begin{array}{l}\text { Days of lactation } \\
\text { (day) }\end{array}$} & \multicolumn{3}{|c|}{ Group (mean) } \\
\hline & & $\mathrm{HG}$ & WEL & $\mathrm{L}$ \\
\hline \multirow{3}{*}{$\begin{array}{l}\text { Glucose } \\
(\mathrm{mmol} / \mathrm{L})\end{array}$} & 3 & 2.99 & 2.37 & 2.60 \\
\hline & 5 & 2.34 & 2.34 & 1.88 \\
\hline & 28 & 2.40 & 2.44 & 2.30 \\
\hline \multirow{3}{*}{$\begin{array}{l}\text { Insulin } \\
(\mu \mathrm{U} / \mathrm{mL})\end{array}$} & 3 & 6.90 & 7.30 & 6.37 \\
\hline & 5 & 7.65 & 10.92 & 6.79 \\
\hline & 28 & 4.85 & 7.11 & 7.77 \\
\hline \multirow{3}{*}{$\begin{array}{l}\text { IGF-I } \\
(\mathrm{ng} / \mathrm{mL})\end{array}$} & 3 & 50.81 & 91.95 & 105.08 \\
\hline & 5 & $59.53 \mathrm{~b}$ & $114.88 \mathrm{ab}$ & $133.75 \mathrm{a}$ \\
\hline & 28 & 127.71 & 208.05 & 194.49 \\
\hline \multirow{3}{*}{$\begin{array}{l}\mathrm{T}_{3} \\
(\mathrm{ng} / \mathrm{mL})\end{array}$} & 3 & $0.56 \mathrm{~b}$ & $1.02 \mathrm{a}$ & $0.86 \mathrm{ab}$ \\
\hline & 5 & $0.42 \mathrm{~b}$ & $0.72 \mathrm{a}$ & $0.52 \mathrm{ab}$ \\
\hline & 28 & $0.79 \mathrm{~b}$ & $1.16 \mathrm{a}$ & $1.02 \mathrm{ab}$ \\
\hline \multirow{3}{*}{$\begin{array}{l}\mathrm{T}_{4} \\
(\mathrm{ng} / \mathrm{mL})\end{array}$} & 3 & 40.88 & 42.94 & 29.65 \\
\hline & 5 & 19.98 & 24.38 & 21.56 \\
\hline & 28 & 32.93 & 40.17 & 37.56 \\
\hline \multirow{3}{*}{$\begin{array}{l}\text { NEFA } \\
(\mathrm{mmol} / \mathrm{L})\end{array}$} & 3 & $1.02 \mathrm{a}$ & $0.70 \mathrm{~b}$ & $0.69 \mathrm{~b}$ \\
\hline & 5 & 0.95 & 0.85 & 0.84 \\
\hline & 28 & 0.47 & 0.44 & 0.47 \\
\hline \multirow{3}{*}{$\begin{array}{l}\text { BHBA } \\
(\mathrm{mmol} / \mathrm{L})\end{array}$} & 3 & $1.01 \mathrm{~A}$ & $0.68 \mathrm{~B}$ & $0.68 \mathrm{~B}$ \\
\hline & 5 & $1.26 \mathrm{~A}$ & $0.76 \mathrm{~B}$ & $0.79 \mathrm{~B}$ \\
\hline & 28 & 0.75 & 0.72 & 0.76 \\
\hline \multirow{3}{*}{$\begin{array}{l}\text { AST } \\
(\mathrm{U} / \mathrm{I})\end{array}$} & 3 & 78.06 & 66.78 & 68.24 \\
\hline & 5 & 55.89 & 53.96 & 50.96 \\
\hline & 28 & 54.33 & 60.15 & 62.01 \\
\hline
\end{tabular}

a, b, c-means with different letters different significantly, $\mathrm{P} \leq 0.05$.

$\mathrm{A}, \mathrm{B}, \mathrm{C}-$ means with different letters differ significantly, $\mathrm{P} \leq 0.01$.

Experimental groups' decrease of BCS from calving day to $56 \mathrm{~d}$ of lactation: $\mathrm{HG}>0.49 \mathrm{BCS}$; WEL $0.49-0.25$ BCS; L $<0.25$ BCS.

Table 8. The effect of BCS decrease during lactation period on reproductive parameters

\begin{tabular}{|c|c|c|c|}
\hline \multirow{2}{*}{ Item } & \multicolumn{3}{|c|}{ Group (mean) } \\
\hline & HG & WEL & $\mathrm{L}$ \\
\hline Days to first ovulation & 24.92 & 26.71 & 23.00 \\
\hline The conception rate of the first insemination & 0.15 & 0.55 & 0.50 \\
\hline Insemination index & 3.15 & 2.23 & 2.14 \\
\hline Days open & 164.08 & 120.33 & 121.27 \\
\hline
\end{tabular}

Experimental groups' decrease of BCS from calving day to $56 \mathrm{~d}$ of lactation: $\mathrm{HG}>0.49 \mathrm{BCS}$; WEL 0.49-0.25 BCS; L $<0.25$ BCS. 


\section{Discussion}

In the current study, in the AC group ( $\leq 3.5 \mathrm{BCS}$ on calving day), significantly higher concentrations of glucose on 3 and $5 \mathrm{~d}$ of lactation as compared to the MID and FAT groups and of insulin on $28 \mathrm{~d}$ and also of IGF-I on 5 and $28 \mathrm{~d}$ of lactation were recorded. Remppis et al. (2011) showed that IGF-I concentrations decrease in early lactation when a negative energy balance occurs. Pires et al. (2013) recorded that the IGF-I concentration decreases postpartum probably due to the uncoupling of the GH (growth hormone): IGF-I axis. Growth hormones cause the secretion of IGFI from the liver. During the periparturient period, GH induction of hepatic IGF-I production is impaired because low insulin concentrations down-regulate the expression of $\mathrm{GH}$ receptor in the liver. The GH receptor expression in the liver of dairy cows is reduced approximately 2 days before calving until the 2 nd week of lactation. During this time, low IGF-I caused increases in the GH secretion from the hypothalamus, and then circulating a high level of $\mathrm{GH}$, favours lipolysis and results in increased concentrations of NEFA in blood. In our experiment, a significant negative correlation between the BCS on the calving day and the concentration of insulin on $28 \mathrm{~d}$ and of IGF-I on 5 and $28 \mathrm{~d}$ was recorded. Postpartum carbohydrate metabolism was affected significantly by the BCS on the calving day suggesting that concentrations of glucose, insulin and IGF-I were potential indicators positively associated with the energy status.

Also in our study, significantly higher NEFA concentrations on 3 and $5 \mathrm{~d}$ and of BHBA on $28 \mathrm{~d}$ in the FAT group (>3.75 BCS) were found, which were possibly associated with metabolic stress involved in adapting to the new metabolic situation and supporting the fact that enhanced ketogenesis is a consequence of increased fat mobilization. Also, a significant positive correlation between the BCS on the calving day and the concentration of NEFA on $3 \mathrm{~d}(\mathrm{r}=0.34)$ and $5 \mathrm{~d}(\mathrm{r}=0.37)$ was determined. These results confirmed that lipid postpartum metabolism was strongly negatively affected by BCS on the calving day. Moreover, the negative effect of the high BCS on the calving day continued until $28 \mathrm{~d}$ of lactation. In our study, cows in the FAT group ( $>3.5$ points) were characterized by the highest concentration of NEFA in the first week (on day 5 postpartum $1.09 \mathrm{mmol} / \mathrm{L}$ ) released from body fat reserves as effect of negative energy balance during early lactation. In similar studies, Seifi et al. (2007) reported peak concentrations of NEFA on day 7 postpartum $(0.91 \mathrm{mmol} / \mathrm{L})$. Multiparous cows with plasma NEFA concentrations greater than $0.80 \mathrm{mmol} / \mathrm{L}$ during 1-2 weeks postpartum have a 2- to 4-fold greater risk of culling within first 60 days of lactation (Roberts et al., 2012). In our study, the highest concentration of NEFA exceeding the reference values $(0.5-0.7 \mathrm{mmol} / \mathrm{L})$ occurred at 1 week postpartum which was accompanied by an increase in BHBA; however, statistically significant concentrations were recorded approximately 3 weeks later than NEFA in the FAT group (>3.5 BCS) on calving day. van Dorland et al. (2009) found that serum NEFA concentrations increased during the first few weeks after parturition, followed by growing concentrations of BHBA. Moreover, an increase in plasma BHBA concentrations due to enhanced ketogenesis may take some time after enhanced lipolysis, mirrored by elevated plasma NEFA levels. Gonzalez et al. 
(2011) suggested that NEFA concentrations are more sensitive biochemical blood indices before calving than BHBA, which is a better biochemical blood marker postpartum. Nonesterified fatty acids from body lipid reserves are absorbed by the liver, where they may be oxidized to provide energy or partially oxidized to ketone bodies. Moreover, NEFA may be esterified to triglycerides (TG) and accumulate in the liver. Numerous authors suggested that the activity of AST is a sensitive biomarker for the detection and diagnosis of liver diseases (Ping et al., 2012). Djokovic et al. (2015) suggest that correlation between insulin, BHBA and NEFA can be attributed to the development of insulin resistance and fatty liver in cows. In our study, the activity of aspartate aminotransferase (AST) was not significantly affected by BCS on the calving day. In similar studies, Šamanc et al. (2011) suggested that activities of liver enzymes (AST) have high variability and thus low diagnostic values. Negative energy balance is associated with a decrease in the concentration of glucose, insulin and IGF-I and increase in the concentrations of NEFA and BHBA. In our study, BCS on the calving day significantly affects the concentration of glucose. In the FAT group $(>3.75)$ lower $(\mathrm{P} \leq 0.05)$ concentrations on 3 and $5 \mathrm{~d}$ were determined. Šmanc et al. (2015) indicated that the blood serum glucose concentration is consistently lower in high BCS loss cows with significant difference observed at one week before and two weeks postpartum. These results could be explained by a lower gluconeogenic capacity of liver cells in high BCS loss cows. In similar studies, Seifi el al. (2007) showed that serum glucose was not strongly correlated with other energy-related metabolites and it was not a valuable biomarker of the metabolic status of dairy cows. Herdt et al. (1988) explained that, although glucose is the primary metabolic fuel and is absolutely required for the vital organ function, foetal growth and milk production, it is an insensitive measure of the energy status because it is subject to tight homeostatic regulation.

Surprisingly, in our study, BCS on the parturition day did not affect the day to the first ovulation; however, BCS $>3.75$ significantly decreased the conception rate of the first insemination, insemination index and increased the number of days open. The relationship between BCS on calving day and a return to ovulation has been well studied (Butler, 2000), however, their influence on reproductive performance is less known. We suggested that the BCS on the calving day strongly affected biochemical blood indices characterizing lipid and carbohydrate metabolism in the first month of lactation with only a partly a negative effect on reproductive performance. Roche et al. (2013) suggested that BCS at calving of less than 3.25 points is associated with reduced reproductive performance, whereas calving $\mathrm{BCS} \geq 3.5$ is associated with a reduction in early lactation dry matter intake and an increased risk of negative energy balance and metabolic disorders in early lactation. In our study, the lowest conception rate of the first insemination, insemination index and thereby the longest days open in the FAT group ( $>3.75$ BCS points) and also, the lowest concentration of glucose, insulin and IGF-I and the highest concentration of NEFA and BHBA were recorded. We suggest that a higher than recommended level of fat reserves at calving estimated by BCS could negatively affect the oocyte quality. The physiological pathways by which the hypothalamic-pituitary-ovarian axis send information about the energy status involve several metabolites and hormones 
such as GH, IGF-I, and insulin. These indicators are negatively correlated with a higher than recommended level of fat reserves on the calving day. Cows with ovulatory estrogen-active follicles have higher circulating IGF-I concentrations during the first weeks than cows with anovulatory follicles. Moreover, cows ovulating within 35 days postpartum present higher concentrations of IGF-I, insulin and lower concentrations of NEFA and BHBA (Huszenicza et al., 2001). Holly et al. (1989) found that cows with a negative energy balance in the periparturient period were characterized by lower levels of the IGF-I and LH hormones, which are necessary for the ovarian follicle development. Moreover, an extended period of returning to ovarian activity interfered with the cyclicity of ovulation and impaired the quality of oocytes. Low plasma concentrations of IGF-I adversely affected reproduction by causing a dominant follicle to fail to reach the ovulatory size. According to Chagas et al. (2007), insulin and IGF-I directly affect ovarian activity by an increase in the sensitivity to $\mathrm{LH}$ and $\mathrm{FSH}$, and also these hormones could be the link connecting the influence of BCS and energy changes on fertility. Konigsson et al. (2008) suggested that IGF-I is an extremely sensitive signal between metabolism and reproduction, and cows with earlier resumption of postpartum ovarian activity had higher IGF-I levels in the first two weeks after calving.

Our study reported the effect of decrease of BCS level during the early lactation period on blood metabolite indices. The highest concentrations of NEFA and BHBA in the HG group $>0.49$ points were recorded. There was a significant interaction between groups of decrease in BCS during early lactation and time of blood sampling on the concentration of BHBA. Moreover, in the HG group ( $>0.49 \mathrm{BCS})$ the higher concentration of BHBA, exceeding the reference value $(0.6-1.0 \mathrm{mmol} / \mathrm{L})$ at 1 week postpartum was analyzed. Furthermore, a positive correlation between the decrease in BCS during early lactation and the concentration of NEFA on 3 and $5 \mathrm{~d}$ and of BHBA on 3 and 5 d of lactation was noted. Busato et al. (2002) found the highest increase in blood plasma NEFA in cows that lost $>0.75$ BCS during the transition period. The increased circulating concentration of BHBA observed concomitantly with NEFA is indicative of enhanced ketogenesis as a consequence of negative energy balance. In the current study, in the HG group, the lowest concentration of triiodothyronine $\left(\mathrm{T}_{3}\right)$ on 3, 5 and $28 \mathrm{~d}$ of lactation compared to L group were analysed. Moreover, there was noted a significant negative correlation between the decrease in BCS during early lactation and concentrations of IGF-I on $5 \mathrm{~d}$ and of $\mathrm{T}_{3}$ on $3 \mathrm{~d}$. Thyroid hormones: triiodothyronine $\left(\mathrm{T}_{3}\right)$ and thyroxine $\left(\mathrm{T}_{4}\right)$ are indicators of adaptation to negative energy balance (Reist et al., 2002). They are positively correlated with the energy balance (Klimiene et al., 2008). Blood levels of thyroid hormones in perinatal cows decrease, particularly in early lactation, when body reserves are mobilized for high milk production (Djokovic et al., 2015).

In our experiment the level of the decrease in BCS during early lactation did not affect significantly the fertility parameters measured. Negative energy balance (NEB) is characteristic during transition period. Dairy cows in NEB are forced to mobilize their body fat reserves and loss of BCS. Šamanc et al. (2015) suggested that in obese dairy cows the risk for their health disorders increased during transition period and in early lactation period. However, not all obese cows develop metabolic 
diseases which could influence reproductive performance after parturition, indicating there are other factors. However, Butler (2000) reported that cows losing less than $0.5 \mathrm{BCS}$ during the first 30 days postpartum took an average of 30 days from calving to the first ovulation. The same study showed that cows with a decrease of 0.5-1 BCS point took 36 days and cows losing more than 1 BCS point took 50 days to the first ovulation. Butler (2000) found that cows losing one or more points of $\mathrm{BCS}$ ( 0 to 5 point scale) during early lactation are at the greatest risk of low fertility with a conceptions rate of 17-38 percent. Therefore, Crowe (2008) confirmed that the physiologically safe limit of deterioration in the condition may be the loss of 0.5 BCS.

We suggest that the body condition score on the calving day and its decrease during early lactation could significantly determine the metabolic status and partly the fertility of high-yielding cows. We concluded that the body condition score (more than 3.51 BCS points) on the calving day had a significantly negative effect on the metabolic status of dairy cows in the postpartum period estimated according to the concentrations of IGF-I, insulin, glucose and reproductive performance such as the conception rate of the first insemination, insemination index and days open. Moreover, a decrease in BCS higher than 0.5 points of BCS during early lactation resulted in an increase in the concentration of NEFA and BHBA without significantly affecting the fertility parameters. We suggested that the concentration of insulin-like growth factor (IGF-I) and nonesterified fatty acids (NEFA) in blood serum were the most sensitive biochemical markers of the metabolic status of high-yielding dairy cows.

\section{References}

Akbar H., Grala T.M., Vailati Riboni M., Cardoso F.C., Verkerk G., Mc Gowan J., Macdonald K., Webster J., Schutz K., Meier S., Matthews L., Roche J.R., L o o r J.J. (2015). Body condition score at calving affects systemic and hepatic transcriptome indicators of inflammation and nutrient metabolism in grazing dairy cows. J. Dairy Sci., 98: 1019-1032.

B u s a to A., Fa is s le D., K u p fer U., B 1 u m J.W. (2002). Body condition scores in dairy cows: associations with metabolic and endocrine changes in healthy dairy cows. J. Vet. Med. A Physiol. Pathol. Clin. Med., 49: 455-460.

B utle r W.R. (2000). Nutritional interactions with reproductive performance in dairy cattle. Anim. Reprod. Sci., 60: 449-457.

Chag a s L.M., B as s J.J., B 1 a che D., B urke C.R., K a y J.K., Lind s y D.R., L u c y M.C., Martin G.B., Meier S., Rhodes F.M., R oche J.R., Thatcher W.W., Webb R. (2007). New perspectives on the roles of nutrition and metabolic priorities in the subfertility of high-producing dairy cows. J. Dairy Sci., 90: 4022-4032.

Ch an d r a G.,A g g a rw a 1 A., S in gh A.K., K u m ar M., K u s h w a h a R., S ing h A., S ing h Y.K. (2011). Negative energy balance and reproduction. Agric. Rev., 32: 246-254.

Cincović R.M., B eli ć B., Radojičić B., Hristov S., Đoković R. (2012). Influence of lipolysis and ketogenesis to metabolic and hematological parameters in dairy cows during periparturient period. Acta Vet. Beograd., 62: 429-444.

Crow e M.A. (2008). Resumption of ovarian cyclicity in post-partum beef and dairy cows. Reprod. Domest. Anim., 43: 20-28.

Djoković R., Cincović M., Belić B., Toholj B., Davidov I., Hristovska T. (2015). Relationship between blood metabolic hormones, metabolites and energy balance in Simmental dairy cows during prepartum period and lactation. Pak. Vet. J., 35: 163-167. 
D u n c o m ble W.G. (1964). The colorimetric micro-determination of non-esterified fatty acid in plasma. Clin. Chim. Acta, 9: 122-125.

E d m o n s o n A.J., L e a n I.J., We a ver L.D., F a rver T., We b s ter G. (1989). A body condition scoring chart for Holstein dairy cows. J. Dairy Sci., 72: 68-78.

G e r 1 o f f B.J. (2000). Dry cow management for the prevention of ketosis and fatty liver in dairy cows. Vet. Clin. N. Am.-Food A., 16: 283-292.

Gonzales F.D., Mu ino R., P e re ir a V., C a mpos R., B en ed ito J.L. (2011). Relationship among blood indicators of lipomobilization and hepatic function during early lactation in highyielding dairy cows. J. Vet. Sci., 12: 251-255.

Gross J., van Dorland H.A., Bruckmaier R.M., Schwarz F.J. (2011). Performance and metabolic profile of dairy cows during a lactational and deliberately induced negative energy balance with subsequent realimentation. J. Dairy Sci., 94: 1820-1830.

H e r d t T.H. (1988). Fatty liver in dairy cows. Vet. Clin. N. Am.-Food A., 4: 269-287.

H o 11 y J.M.P., W a s s J.A.H. (1989). Insulin-like growth factors; autocrine, paracrine or endocrine? New perspectives of the somatomedin hypothesis in the light of recent developments. J. Endocrinol., 122: 611-618.

Huszenicza G., Kulcs ar M., Nicolic A.J., Schmidt J., Korodi P., Katai L., Dielem an S., R ib i c z e i - S z a b o A., R u d as P. (2001). Plasma leptin concentration and its interrelation with some blood metabolite, metabolic hormones and the resumption of cyclic ovarian function in postpartum dairy cows supplemented with Monensin or inert fat in feed. Brit. Soc. Anim. Sci., 35: 405-409.

Kawashima C., Fukihara S., Maeda M., Kaneko E., Montoya C.A., Matsui M., Shimizu T., Matsunaga N., Kida K., Miyake Y., Schams D., Miyamoto A. (2007). Relationship between metabolic hormones and ovulation of dominant follicle during the first follicular wave post-partum in high-producing dairy cows. Reproduction, 133: 155-163.

Klimiene I., Mockeliunas R., Š pakauskas V., Černauskas A., S akalauskiene R. (2008). Metabolic changes of thyroid hormones in cattle. Vet. Ir. Zootech., 42: 3-13.

Konig s son K., S a vo in i G., Govon i N., Invernizzi G., Prandi A., K ind ahl H., Ve r o n e s i M.C. (2008). Energy balance, leptin, NEFA and IGF-I plasma concentrations and resumption of post-partum ovarian activity in Swedish red and white breed cows. Acta Vet. Scand., 50: 3.

Locher L., Häussler S., Laubenthal L., Singh S.P., Winkler J., Kinoshita A., K e né z A., R eh a g e J., H u b e r K., S a u erw e in H., D än icke S. (2015). Effect of increasing body condition on key regulators of fat metabolism in subcutaneous adipose tissue depot and circulation of nonlactating dairy cows. J. Dairy Sci., 98: 1057-1068.

Mat thews L.R., Cameron C., Sheahan A.J., Kolver E.S., Roche J.R. (2012). Associations among dairy cow body condition and welfare-associated behavioral traits. J. Dairy Sci., 95: $2595-2601$.

Ping L., Bao X.H., Xian L.Y., Xiao L.H., Jian B.H., Yin H.H., Pei N., Hui F.D., X i a n g X.D. (2012). Bioactivity evaluation of certain hepatic enzymes in blood plasma and milk of Holstein cows. Pakistan Vet. J., 32: 601-604.

Pires J.A.A., Delavaud C., F a ulconnier Y., Pomiès D., Chilliard Y. (2013). Effects of body condition score at calving on indicators of fat and protein mobilization of periparturient Holstein-Friesian cows. J. Dairy Sci., 96: 6423-6439.

R e m p p i s S., S t e in g a s s H., G r u b e r L., S c h e n k e l H. (2011). Effects of energy intake on performance, mobilization and retention of body tissue, and metabolic parameters in dairy cows with special regard to effects of pre-partum nutrition on lactation. Asian-Aust. J. Anim. Sci., 4: 540-572.

Roberts T., Chapinal N., Le B lan c S.J., Kelt on D.F., Dubuc J., Duffield T.F. (2012). Metabolic parameters in transition cows as indicators for early lactation culling risk. J. Dairy Sci., 95: 3057-3063.

Roche J.R., Macd on ald K.A., S chütz K.A., Mat thew s L.R., Verkerk G.A., Me i e r S., Loor J.J., Rogers A.R., McGowan J., Morgan S.R., Taukiri S., Webster R.J. (2013). Calving body condition score affects indicators of health in grazing dairy cows. J. Dairy Sci., 96: 5811-5825.

Šamanc H., Kirovski D., S tojić V., Stojanovic D., Vujanac I., Prodanovic R., Bojkovic-Kovacevic S. (2011). Application of the metabolic profile test in the prediction and diagnosis of fatty liver in Holstein cows. Acta Vet., 61: 543-553. 
Šamanc H., Gvozdić D., Fratrić N., Kirovski D., Djokovi R., Sladojevic Z., C in c ov i c M. (2015). Body condition score loss, hepatic lipidosis and selected blood metabolites in Holstein cows during transition period. Anim. Sci. Pap. Rep., 1: 35-47.

Seifi H.A., Gorji-Dooz M., Mohri M., Dalir-Nagadeh B., Farzaneh N. (2007). Variations of energy-related biochemical metabolites during transition period in dairy cows. Comp. Clin. Pathol., 16: 253-258.

Yel1 ow R.S., B e r s o n S.A. (1960). Immunoassay of endogenous plasma insulin in man. J. Clin. Invest., 39: 1157-1175.

van Dorland H.A., Ri chter S., More 1 I., D oherr G.H., C a s tro N., B ruck ma ier R.M. (2009). Variation in hepatic regulation of metabolism during the dry period and in early lactation in dairy cows. J. Dairy Sci., 92: 1924-1940.

Received: 11 II 2015

Accepted: 23 IX 2015 